\title{
Identifying relations between posture and pain in lower back pain patients: a narrative review
}

\author{
Sai Kripa (1) and Harmanpreet Kaur
}

\begin{abstract}
Posture is a "body's attitude or the positioning of the limbs when standing or sitting." There are many examples of different postures which include lordotic posture, swayback posture, flat back, and anterior pelvic tilt. Everyone in some of the other parts of their life considers pain as an unpleasant feeling or sensation that is experienced. Specifically, low back pain can be relentless and daunting to many people who often recovered without the need of a health care professional or any treatment by changing their posture or performing the movement. Various factors are leading to low back pain other than the postural fault, for instance, age, sedentary lifestyle, anxiety, and sleep. However, for back pain, posture has become deep-rooted in people's thoughts. Health care professionals have instructed people to correct their posture to fight back pain. As people become older, the posture becomes worse, but this does not appear to cause pain. If any person cannot move his/her body, that does not mean that they are having a problem involving posture; that is actually because of a problem relating to movement. A study proved that there is no difference in the lordotic angle of the populace having an issue with LBP. There is a decrease in the range and speed of the movement performed. What matters is the movement rather than the appearance of standing or sitting. The primary aim of this paper is to improve knowledge and understanding of the association between posture and LBP, as, speaking about recent researches, they have observed no association between posture and LBP. There are many studies published to support this evidence. People call the importance of posture and alignment for while performing a heavy deadlift, land a jump, or any strenuous activity. Therefore, an urge to write a paper on this topic is to change the mindset of many people worrying out there about their postural faults or their appearances by providing information about varying their static posture to conform to some ideal and keep moving to improve their function.
\end{abstract}

Keywords: Posture, Pain, Movement, Low back pain, Back pain, Static posture, Postural problem, Movement problem, LBP

Posture is not a position, however, a complex motif of reflexes, behaviors, and adaptive responses to something that opposes and withstands from being straight-up or functional by the concerted activity of many muscles employed to manage stability [1]. Various groups of muscles are critically important in maintaining posture, including the hamstrings and broad back muscles, and preserve balance during motion. Although the ligament

* Correspondence: saikripa2008@gmail.com

Department of Physiotherapy, Chandigarh University, Mohali, India helps to keep the body together, these postural muscles prevent the forces of gravity from moving us forward while operating properly. Discussing various clinically observed postures in standing includes lordotic posture, swayback posture, flat back, and anterior pelvic tilt [2]. However, criticizing these postures as causes of people's pain is often instinctive and considered faulty postures. Evidence-based practice is a probability game, and the chance of posture being a reason for several musculoskeletal issues is strongly shaped. Primarily, on talking
Springer Open (c) The Author(s). 2021 Open Access This article is licensed under a Creative Commons Attribution 4.0 International License, which permits use, sharing, adaptation, distribution and reproduction in any medium or format, as long as you give appropriate credit to the original author(s) and the source, provide a link to the Creative Commons licence, and indicate if changes were made. The images or other third party material in this article are included in the article's Creative Commons licence, unless indicated otherwise in a credit line to the material. If material is not included in the article's Creative Commons licence and your intended use is not permitted by statutory regulation or exceeds the permitted use, you will need to obtain permission directly from the copyright holder. To view a copy of this licence, visit http://creativecommons.org/licenses/by/4.0/. 
about good-bad posture, there is no gold standard definition for it. Second, there is no single correct posture. Apart from common postural perceptions, there is no sound evidence that there is one ideal posture or that preventing "incorrect postures" will eliminate back pain [3].

Low back pain is distress situated inferior to the 12th rib margin and superior to the lower gluteal folds, with the presence or absence of leg pain. Researches report that almost $18 \%$ of the population would develop LBP during their lifetime [4]. The most prevalent type of LBP is "non-specific LBP" because of non-identifiable clinical pathology. Classification of low back pain based on duration into three sub-types includes acute, sub-acute, and chronic LBP. Acute LBP is a period of LBP lasting less than 6 weeks, sub-acute LBP between 6 and 12 weeks, and chronic LBP lasting 12 weeks or further. Chronic LBP is LBP which has endured for over 3 months [5]. Researching the risk factors for LBP can help to minimize LBP and reduce the impact of acute LBP from transforming to chronic LBP. The leading risk factors of low back pain include age, sedentary lifestyle, anxiety, and sleep [4]. Besides various risk factors, I think the postural factor to be the greatest risk factor for LBP. According to assertions, bad posture induces back pain, or patients can get rid of low back pain by focusing on their posture. Maintaining the same posture for a prolonged period can also cause issues. If a person sustains any posture that does not move or for a longer period, it is not considered a problem relating to posture; however, it is a problem involving movement. The principal motive of this article is to find the exact relationship between posture and pain if exists.

\section{Is there any association between posture and low back pain?}

If anyone has a lordosis or increase in curvature at the lower back, people may say that they are having the lower cross syndrome. In such cases, there occurs anterior pelvic tilt, and the belly facing anteriorly. To correct this issue, ask people to go for strengthening of abdominal and gluteal muscles, followed by stretching of hip flexor muscles. Also, ask them to tuck the tummy in and to keep the core muscles stronger. Another common theory is that observing for any kind of asymmetry in the body can produce pain. For instance, a physiotherapist might seek to locate and do correction in the orientation in your pelvic tilt, since they are anxious that this will bring rotation or flexion in your spine. They might be curious how there is leg length discrepancy observed with one leg longer than the other, as it will cause one side of their pelvis to tilt superiorly. Apart from that, sustained postural pressures at work or athletic events can be the source of LBP. Perhaps, the depth of the evidence is best reflected in an article that reviewed over fifty-four reports on the relationship between posture and pain [6]. Besides, it is impressive considering studies, Papageorgeoui, got many variables that are associated with LBP, for example, exercise, work satisfaction, education level, stress, and smoking

\section{Anterior pelvic tilt}

Let us look at a specific postural problem, like an anterior pelvic tilt. They associated faulty posture with several musculoskeletal disorders, and it connected this to the pelvic position. A study [7] observes the incidence in the population who are completely healthy and do not show any symptoms with an absence of pain; a huge $80 \%$ of the population has one. We also identified the existence of asymmetry as a sign of pelvic and lumbar spine tension [7] correlated with LBP. However, in both these articles, they observed the relationship was possibly weak. Another cross-sectional study [8] has observed that there is no substantial difference between subjects who have no symptoms and among subjects having LBP in the anterior pelvic tilt [9].

\section{Lumbar lordosis}

The theory is that an increase (and often decreases) in the curve of the lumbar spine causes back pain and often combined with the belief that the pelvic tilt affects the size of the lumbar curve; however, lumbar curves do not seem to be a factor in lower back pain anyhow. Way back in 1990, [10] examined their clients, physicians' standing posture with 25 healthy subjects, and noticed no association between pelvic angle tilt and the lumbar curve. As a result, looking at the pelvic position gives us little of what happens at the lumbar spine, which is much more difficult to quantify. A study investigated the variation of 400 people's standing posture, 332 with no pain and 83 with low back pain, and observed each one of us carry out it slightly differently each time we stand. In conclusion, standing is highly individual and poorly reproducible. An irreproducible standing posture may cause misinterpretation of radiological measurements, inaccurate diagnosis, and likely unnecessary management [11]. Another study observed no substantial variations in lordosis or leg length disparity among 321 males with extreme LBP, mild pain, or no pain divided into 3 groups [12]. An epidemiologic study identified that teenagers with asymmetry in posture, severe increase in thoracic curvature, or lower back curvature are no more likely than peers with a healthy posture to experience back pain in adulthood [13]. Although it has shown that the occurrence of back pain during pregnancy is large, certain studies have examined the changes in posture that take place during pregnancy and their association with LBP. However, pregnant women with significant 
changes in the lower back curve are no longer to experience back pain [14].

\section{Postural behavior}

A domain, often measured in MT and PT, is how "accurately" a subject uses their body-their "postural behavior." We assume prolonged postural pressures at work or athletic events to be a source of LBP as postulated. However, in [15], this study proved the statement wrong and concluded that the populace indulged in working or occupations and following certain awkward postures is not leading to high-intensity LBP. The postures, for example, are continued standing, bending, twisting, kneeling or squatting, sitting at work, and continuous sitting and leisure time at work. They also found that physical recreational practices such as sports or exercises, sitting, or long-standing/walking shown no correlation with LBP.

\section{Leg length discrepancy}

Most people have a slight variation in the lengths of their legs. The difference is slight and marginal for others and will not be a factor in low back pain. It is the case for people if their leg length is less than $5 \mathrm{~mm}$. However, a belief that a discrepancy in leg lengths of more than $5 \mathrm{~mm}$ or $1 / 4$ inch may contribute to LBP. Later, a study claims there is no relation between leg length discrepancy and LBP. It shows that shortening of the lower extremity is not a major causal factor for chronic back pain, regardless of the anatomical cause. The study also examined that the subjects who had a long-standing difference in lower extremity limb length over $5 \mathrm{~cm}$ showed no association with LBP [16].

\section{Tissue adaptive responses}

The tissue responds brilliantly to heightened loads. In reality, going to the gym and loading your tissues with weights, or adjusting to an increase in load is what you are doing with your tissues. Such loads ought to be larger than the normal poor posture, even in more severe joint ranges. The same could be true for a muscle being "overworked" and drained as a source of pain because of faulty posture. We can give possible three explanations for posture not related to pain.

\section{Tissues accommodate to stress eventually}

The poor posture leading to pain is the primary hypothesis placed on the fact that it causes undue mechanical stress in different places, causing micro-damage that adapts with duration. While there is, fail it to understand that tissues can adapt to stress.
Tissue damage does not correlate with pain

Posture cannot cause pain because bad posture leads to tissue damage and any kind of tissue damage is not equivalent to pain. The studies consistently provide evidence that a greater percentage of people with no pain at their lower back and shoulders, tears in their rotator cuff, and no issue when you go for an MRI, there can be a higher chance of observing for significant damages in areas where you are not feeling any pain. It is because according to [17] pain is complex and damage in tissue is a single factor in pain.

\section{People have a unique structural appearance}

Poor posture does not equate to pain, since everyone has a unique structural appearance. It can be effectively determined to a certain degree, standing, sitting, or moving with comfort by the size and shape of the bones. Therefore, any dysfunction in the alignment to one individual will be finest for the other person. Because of these individual variations, it is counterproductive to equate the posture to any perfect model and seek to plan corrections.

\section{Conclusions}

The shreds of evidence suggest that if there is any association observed between posture and pain, it is meager. Even if there is a linkage between pain and posture, this does not suggest a fundamental association. Pain can lead to poor posture; however, not poor posture can lead to pain. It is important to understand the progress in trying to change posture, maybe through exercise or movement, which will help in declining the pain from different body parts. Subtle postural changes are a safer comfort strategy than keeping an "erect" pose all the time. Therefore, static posture is not a primary factor in LBP. As an alternative, remain comfortable, keep moving, work on improving your function, and be positive to use fine alignment during strenuous exercises.

"Your best posture is your next posture"-Morgan

Freeman

\section{Abbreviation \\ LBP: Low back pain}

Acknowledgements

Not applicable.

\footnotetext{
Authors' contributions

The corresponding author "SK" contributed to the "Abstract," "Conclusion," and the first section of the review, i.e., "Is there any association between posture and low back pain?" The second author "HK" contributed her effort in finding necessary articles to support our research relating to tissue adaptive responses. She has written the second section of the review, i.e., "Tissue adaptive responses," and the literature gap of the review article. I equally distributed the efforts in writing the review article among the authors. All authors have read and approved the manuscript.
} 


\section{Funding}

Not applicable.

Availability of data and materials

Not applicable.

\section{Declarations}

Ethics approval and consent to participate

Not applicable.

\section{Consent for publication}

Not applicable.

\section{Competing interests}

The authors declare that they have no competing interests.

Received: 27 July 2021 Accepted: 19 September 2021

Published online: 30 November 2021

\section{References}

1. Levangie PK, Norkin CC. Joint structure and function: a comprehensive analysis. 4th ed. Philadelphia: F.A. Davis Co; 2005

2. Smith A, Sullivan PO, Straker L. Classification of sagittal thoraco-lumbo-pelvic alignment of the adolescent spine in standing and its relationship to low back pain. 2008;33(19):2101-7. https://doi.org/10.1097/BRS.0b013e31817ec3 bo.

3. Sullivan PO, Dip G, Ther M, Physio D, Nolan D. "Sit up straight": time to reevaluate. Spine-Lippincott. 2019;49(8):562-4. https://journals.Iww.com/ spinejournal/pages/default.aspx.

4. Lionel KA. Risk Factors for Chronic Low Back Pain in Adults: A Case Control Study Done in Sri Lanka. J Pain Relief. 2014;3:162. https://doi.org/10.4172/21 67-0846.1000162.

5. Balagué F, Cardon G, Eriksen HR, Henrotin Y, Lahad A, Leclerc A, et al. Chapter 2 European guidelines for prevention in low back pain. Eur Spine J. 2006;15:136-68. https://www.springer.com/journal/586.

6. Toftgaard S, Dc C, Dc JH. Spinal curves and health: a systematic critical review of the epidemiological literature dealing with associations between sagittal spinal curves and health. J Manipulative Physiol Ther. 2008; Available from:;31(9):690-714. https://doi.org/10.1016/j.jmpt.2008.10.004.

7. Herrington $L$. Assessment of the degree of pelvic tilt within a normal asymptomatic population. Man Ther. 2011;16(6):646-8. Available from: https://doi.org/10.1016/j.math.2011.04.006.

8. Nourbakhsh MR, Arab AM. Relationship between mechanical factors and incidence of low back pain. J Orthop Sports Phys Ther. 2002;32(9):447-60. https://doi.org/10.2519/jospt.2002.32.9.447.

9. Preece SJ, Willan P, Nester CJ, Graham-Smith P, Herrington L, Bowker P. Variation in pelvic morphology may prevent the identification of anterior pelvic tilt. J Man Manipulative Ther. 2008;16(2):113-7.

10. Heino JG, Godges JJ, Charles L. Relationship between hip extension range of motion and postural alignment. 1990;(December).

11. Schmidt H, Bashkuev M, Weerts J, Graichen F, Altenscheidt J, Maier C, et al. Address of corresponding author. J Biomech. 2017; Available from:;70:67-76 https://doi.org/10.1016/j.jbiomech.2017.06.016.

12. Pope $\mathrm{MH}$, Bevins T, Wilder DG, Frymoyer JW. The relationship between anthropometric, postural, muscular, and mobility characteristics of males ages 18-55. Spine (Phila Pa 1976). 1985;10(7):644-8. https://doi.org/10.1097/ 00007632-198509000-00009.

13. Dieck GS, Kelsey JL, Goel VK, Panjabi MM, Walter SD, Laprade MH. An epidemiologic study of the relationship between postural asymmetry in the teen years and subsequent back and neck pain. Spine (Phila Pa 1976). 1985; 10(10):872-7. https://doi.org/10.1097/00007632-198512000-00002.

14. Franklin ME, Conner-Kerr T. An analysis of posture and back pain in the first and third trimesters of pregnancy. J Orthop Sports Phys Ther. 1998;28(3): 133-8.

15. Lederman $\mathrm{E}$. The fall of the postural-structural-biomechanical model in manual and physical therapies: exemplified by lower back pain; 2010. p. 114

16. Garcia S. Likely explanation; 2000. p. 256-8.

17. Melzack R, Katz J. Pain. Wiley Interdiscip Rev Cogn Sci. 2013:4(1):1-15. https://doi.org/10.1002/wcs.1201. Epub 2012 Oct 4

\section{Publisher's Note}

Springer Nature remains neutral with regard to jurisdictional claims in published maps and institutional affiliations.

\section{Submit your manuscript to a SpringerOpen ${ }^{\circ}$ journal and benefit from:}

- Convenient online submission

- Rigorous peer review

- Open access: articles freely available online

- High visibility within the field

- Retaining the copyright to your article

Submit your next manuscript at $\boldsymbol{\nabla}$ springeropen.com 